\title{
Potential of Phytase and Citric Acid Treated Canola Meal Based Diet to Enhance the Minerals Digestibility in Labeo rohita Fingerlings
}

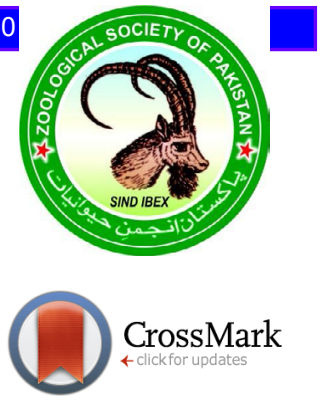

\author{
Rana Zeeshan Habib ${ }^{1}$, Muhammad Afzal' ${ }^{1}$, Syed Zakir Hussain Shah ${ }^{2, *}$, \\ Mahroze Fatima ${ }^{3}$, Muhammad Bilal ${ }^{4}$ and Syed Makhdoom Hussain ${ }^{5}$
}

${ }^{1}$ Fish Nutrition Laboratory, Department of Zoology, Wildlife \& Fisheries, University of Agriculture, Faisalabad

${ }^{2}$ Department of Zoology, University of Gujrat, Gujrat

${ }^{3}$ Department of Fisheries and Aquaculture, University of Veterinary and Animal Sciences, Lahore

${ }^{4}$ Industrial Biotechnology Laboratory, Department of Biochemistry, University of Agriculture, Faisalabad

${ }^{5}$ Department of Zoology, Government College University, Faisalabad

\section{A B S T R A C T}

Present trial was conducted to investigate the effect of phytase (PHY) and citric acid (CA) supplementation on minerals digestibility of Labeo rohita fingerlings fed on canola meal based diet. Nine experimental diets were prepared by supplementing CA (\%) and PHY (FTU/kg) at the level of 0,0 (control); 0, 1000; 0,$2000 ; 1.5,0 ; 1.5,1000 ; 1.5,2000 ; 3,0 ; 3,1000 ; 3,2000$ respectively. Chromic oxide was used as inert marker in diets to estimate mineral digestibility. Fish fed on PHY supplemented diet showed higher apparent digestibility coefficient (ADC\%) of $\mathrm{Ca}, \mathrm{P}, \mathrm{Na}, \mathrm{K}, \mathrm{Mg}, \mathrm{Fe}, \mathrm{Cu}, \mathrm{Mn}, \mathrm{Zn}$. Similarly, CA addition also improved $(p<0.05) \mathrm{ADC} \%$ of $\mathrm{Ca}, \mathrm{P}, \mathrm{Na}, \mathrm{K}, \mathrm{Mg}, \mathrm{Fe}$ and $\mathrm{Cu}$, however, $\mathrm{ADC} \%$ of $\mathrm{Mn}$ and $\mathrm{Zn}$ remained unaffected. Also, acidification of PHY treated diet with CA significantly $(p<0.05)$ improved the mineral digestibility performance of $L$. rohita. In conclusion, both the additives (CA and PHY) showed improved digestibility of minerals individually as well as in combination.

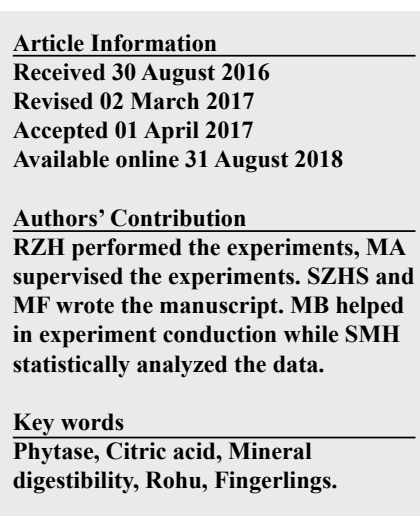

\section{INTRODUCTION}

$\mathrm{L}$ abeo rohita is a fish of prime importance in aquaculture industry of Pakistan due to its high quality flesh. Fish meal is being used as a prominent ingredient in fish feed, but its high price and limited supply has compelled the researchers to search for alternative feed sources, like plant protein based feed ingredients. Canola meal is one of the most promising fish feed source having $38 \%$ protein and is less in antithyroid factors, erucic acid and glucosinolates (Bell, 1993). The problem associated with its use is the presence of anti-nutritional factors like phytate. Canola meal constitutes $3.1 \%$ to $3.6 \%$ phytate which have deleterious effects on the fish gut that ultimately leads to poor growth performance of fish (Usmani and Jafri, 2002). Phytate represents 60 to $80 \%$ of the total phosphorus present in plant feed stuff which cannot be utilized by agastric or mono-gastric fish species like L. rohita due to lack of intrinsic phytase activity (Ogino et al., 1979). Phytate is highly negative charged ion and have adverse effects on

\footnotetext{
Corresponding author: zakiruaf@gmail.com 0030-9923/2018/0006-2045 \$ 9.00/0

Copyright 2018 Zoological Society of Pakistan
}

mineral absorption by making insoluble complexes with divalent and trivalent cations like $\mathrm{Ca}^{+2}, \mathrm{Zn}^{+2}, \mathrm{Mn}^{+2}, \mathrm{Cu}^{+2}$ and $\mathrm{Fe}^{+2 /+3}$ (Kumar et al., 2010). Poor phytate degradation also contribute to eutrophication which have detrimental effect on fresh water bodies (Persson et al., 1998).

Microbial phytase (PHY) is enzyme capable of removing phosphate group from phytate and making it available to fish for utilization and absorption (Baruah et al., 2007). Sugiura et al. (2001) reported increased mineral digestibility of rainbow trout as a result of PHY supplementation. Similarly, Laining et al. (2010) concluded that $2000 \mathrm{FTU} / \mathrm{kg}$ PHY enhanced mineral digestibility performance of juvenile tiger puffer (Takifugu rubripes) efficiently. A comparatively high level (8000 FTU $/ \mathrm{kg}$ ) of PHY supplementation was considered optimum to enhance the digestibility of $\mathrm{Mg}, \mathrm{P}, \mathrm{Ca}, \mathrm{Fe}$ and $\mathrm{Mn}$ in tilapia when fed soybean meal-based diet (Nwanna, 2005). However, PHY activity is $\mathrm{pH}$ dependent and it is highly active at low pH of gut (Baruah et al., 2007). Acid producing ability of carnivore fishes lower the $\mathrm{pH}$ of gut but monogastric fishes lack this ability (Ogino et al., 1979). It is well documented that addition of organic acids such as citric acid (CA) in fish diet lowers the $\mathrm{pH}$ of digestive 
tract and enhances the PHY efficacy Baruah et al. (2005). Apart from providing the optimum conditions to the PHY, CA itself dephosphorylate phytate complex and enhance the availability of $\mathrm{P}$ and other minerals (Zyla et al., 1995). Khajepour and Hosseini (2011) reported that addition of CA in the feed of Beluga (Huso huso) efficiently enhanced the $\mathrm{Ca}$ and $\mathrm{P}$ contents of fish. Enhanced utilization of $\mathrm{P}$ and other minerals by supplementation of CA to fish feed was reported by Sugiura et al. (2001).

Thus, the objective of the present study was to investigate the main as well as synergetic effect of phytase and citric acid on mineral digestibility performance of $L$. rohita fingerlings fed canola meal based diet.

\section{MATERIALS AND METHODS}

The present $3 \times 3$ factorial experiment was conducted in the Fish Nutrition Laboratory, Department of Zoology, Wildlife and Fisheries, University of Agriculture, Faisalabad, Pakistan.

\section{Fish and experimental conditions}

The fingerlings were obtained from Government Fish Seed Hatchery, Faisalabad and acclimatized to experimental conditions in laboratory for two weeks in V-shaped tanks (UA system) especially designed for fecal collection from water media. Twelve fingerlings (average weight of $7.61 \mathrm{~g}$ ) were stocked in each tank having $70 \mathrm{~L}$ water capacity. During this period the fingerlings were fed once daily to apparent satiation on the basal diet (Allan and Rowland, 1992). Water quality variables, particularly temperature, $\mathrm{pH}$ and dissolved oxygen were monitored by the usage of Jenway $\mathrm{pH}$ meter (model 3510) and D.O. meter (model 970) respectively during the study period.
Aeration was provided $24 \mathrm{~h}$ to all tanks through capillary system. Before starting the feeding trial, the fingerlings were treated with $5 \mathrm{~g} / \mathrm{L} \mathrm{NaCl}$ solution to make fish free from fungal infection and ectoparasites (Rowland and Ingram, 1991).

\section{Feed ingredients and experimental diets}

The feed ingredients were bought from a commercial feed mill and analyzed for chemical composition following (AOAC, 1995) prior to the formulation of the experimental diet. The feed ingredients were ground and sieved to required particle size before formulation of experimental diets (Table I). All dry ingredients were mixed in electric mixer for 10-20 min, where-after fish oil was gradually added, while mixing constantly. Chromic oxide (1\%) was used as an inert non digestible marker. Citric acid was added at the levels of $(0,1.5$ and $3 \%)$ to dry mixed ingredients to make three test diets. Ten to fifteen percent water was added to prepare suitable dough of each test diet, and was further processed through lab extruder for making floating pellets. Three test diets were made based on 3 concentrations of $\mathrm{CA}$, after pelleting which were further sprayed with three PHY levels (0, 1000 and 2000 FTU kg-1 diet) resulting in the formulation of nine test diets. The phytase (Phyzyme ${ }^{\circledR}$ XP 10000 FTU/g; Danisco Animal Nutrition, Fin-65101 Vaasa, Finland) solution was prepared by dissolving $2 \mathrm{~g}$ of microbial phytase (powder form) into $1 \mathrm{~L}$ of distilled water (Robinson et al., 2002). One unit of phytase activity (FTU) is defined as "the enzyme activity that liberates $1 \mu \mathrm{mol}$ of inorganic orthophosphates per min at $\mathrm{pH} 5.5\left(37^{\circ} \mathrm{C}\right)$ at a substrate (sodium phosphate) concentration of $5.1 \mathrm{mmol} / \mathrm{L} "$ (Engelen et al., 1994). The proximate and mineral composition of experimental diets is given in Table II.

Table I.- Ingredient composition (\%) of experimental diets.

\begin{tabular}{|c|c|c|c|c|c|c|c|c|c|}
\hline \multirow{2}{*}{$\begin{array}{l}\text { CA level (\%) } \\
\text { PHY Level (FTU/kg) }\end{array}$} & \multicolumn{3}{|c|}{$\mathbf{0}$} & \multicolumn{3}{|c|}{1.5} & \multicolumn{3}{|c|}{3} \\
\hline & 0 & 1000 & 2000 & $\mathbf{0}$ & 1000 & 2000 & $\mathbf{0}$ & 1000 & 2000 \\
\hline Test Diets & T1 (Control) & $\mathbf{T} 2$ & T3 & $\mathrm{T} 4$ & T5 & T6 & $\mathbf{T} 7$ & T8 & T9 \\
\hline Fish meal & 12 & 12 & 12 & 12 & 12 & 12 & 12 & 12 & 12 \\
\hline Canola meal & 56 & 56 & 56 & 56 & 56 & 56 & 56 & 56 & 56 \\
\hline Rice polish & 12 & 12 & 12 & 12 & 12 & 12 & 12 & 12 & 12 \\
\hline Wheat flour & 10 & 10 & 10 & 10 & 10 & 10 & 10 & 10 & 10 \\
\hline Fish oil & 6 & 6 & 6 & 6 & 6 & 6 & 6 & 6 & 6 \\
\hline Vitamin premix & 1 & 1 & 1 & 1 & 1 & 1 & 1 & 1 & 1 \\
\hline Minerals & 1 & 1 & 1 & 1 & 1 & 1 & 1 & 1 & 1 \\
\hline Ascorbic acid & 1 & 1 & 1 & 1 & 1 & 1 & 1 & 1 & 1 \\
\hline Chromic oxide & 1 & 1 & 1 & 1 & 1 & 1 & 1 & 1 & 1 \\
\hline Total & 100 & 100 & 100 & 100 & 100 & 100 & 100 & 100 & 100 \\
\hline
\end{tabular}



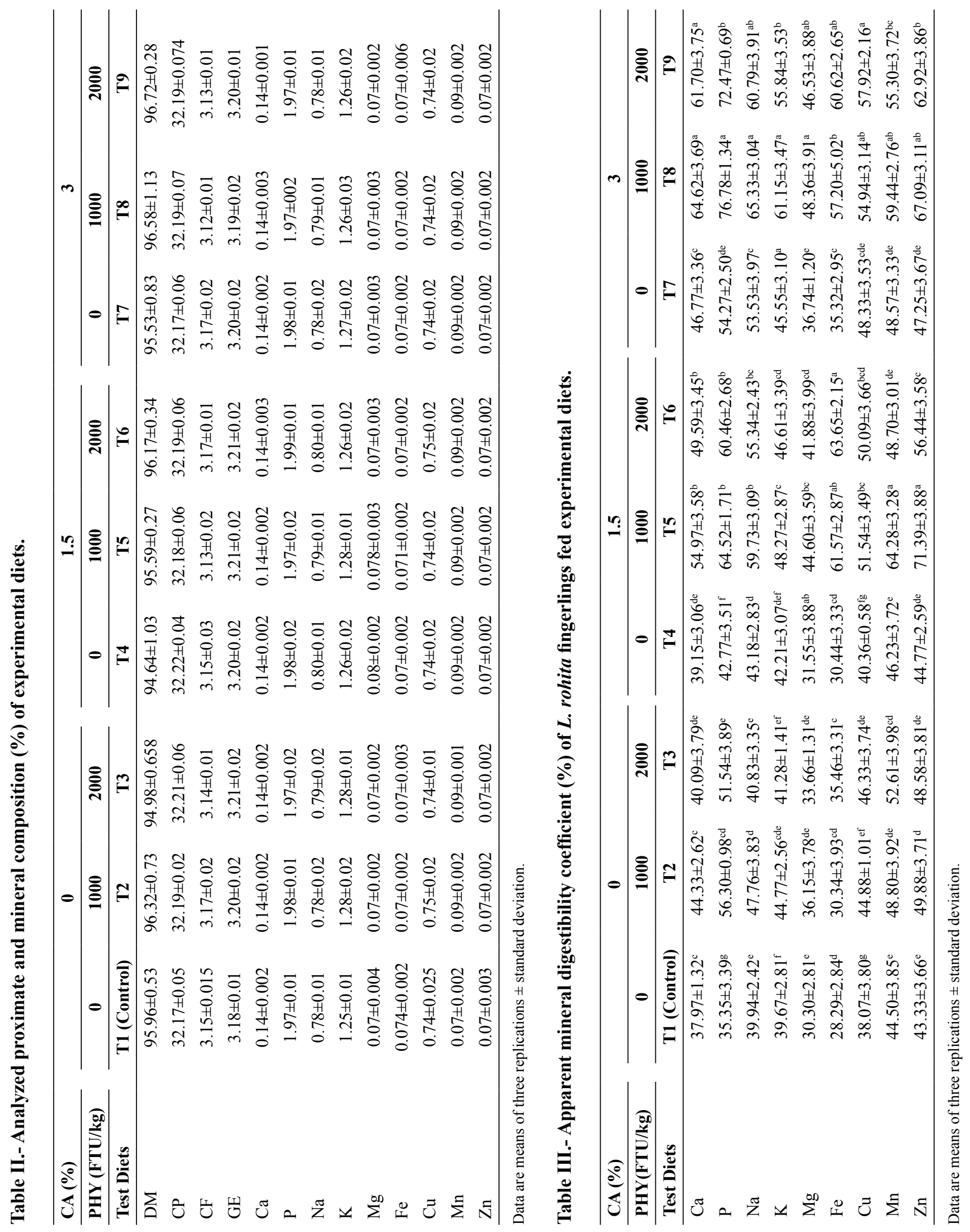


\section{Feeding protocol and sample collection}

The fish fingerlings were fed at the rate of $3 \%$ of live wet weight on their prescribed diet. For each test diet, three replicate tanks were assigned with stocking density of twelve fish in each tank. After the feeding session of $3 \mathrm{~h}$, the uneaten diet was drained out from each tank by opening the valves of the tanks. The tanks were washed completely to remove the particles of diets and refilled with water. After that, the fish were restocked in tanks. The feces will be collected from the fecal collection tube of each tank after $2 \mathrm{~h}$ intervals, by opening the valve I and valve II subsequently. Care was taken to avoid breakage of the thin fecal strings in order to minimize nutrient leaching. Fecal material of each replicated treatment was dried in oven ground and stored for chemical analysis. The experiment lasted for 2 months.

\section{Chemical analysis of feed and feces}

The sample of feed ingredients, test diets and feces were homogenized using pestle and mortar, and analyzed by standard methods (AOAC, 1995). Moisture was determined by oven-drying at $105^{\circ} \mathrm{C}$ for $12 \mathrm{~h}$, crude protein by micro Kjeldahl apparatus, crude fat by petroleum ether extraction method through soxtec HT2 1045 system, crude fiber was determined as loss on ignition of dried lipid-free residues after digestion with $1.25 \% \mathrm{H}_{2} \mathrm{SO}_{4}$ and $1.25 \%$ $\mathrm{NaOH}$, crude ash by ignition at $650^{\circ} \mathrm{C}$ for $12 \mathrm{~h}$ in electric furnace (Eyela-TMF 3100) to constant weight, and gross energy with the help of adiabatic oxygen bomb calorimeter (Parr Instrument Co., Moline, USA). Total carbohydrates (N-free extract) were calculated by difference i.e. total carbohydrate $(\%)=100-($ moisture $\%+\mathrm{CP} \%+\mathrm{EE} \%+$ Ash $\%+\mathrm{CF} \%$ ). Chromic oxide contents in experimental diets and feces were estimated after oxidation with molybdate reagent (Divakaran et al., 2002) using a UVVIS 2001 Spectrophotometer at $370 \mathrm{~nm}$ absorbance.

Apparent nutrient digestibility coefficients (ADC) of test diets were calculated by the formula reported in NRC (1993):

ADC $\%=100-100 \times \frac{\text { Percent marker in diet } \times \text { Percent nutrient in feces }}{\text { Percent marker in feces } \times \text { Percent nutrient in diet }}$

\section{Statistical analysis}

Data of mineral digestibility of experimental diets were subjected to two-way analysis of variance (Steel et al., 1996). The difference among means were compared by Tukey's Honestly Significant Difference Test and considered significant at $p<0.05$ (Snedecor and Cochran, 1991). The CoStat computer package (Version 6.303, PMB 320, Monterey, CA, 93940 USA) was used for statistical analysis.

\section{RESULTS}

The results of main effect of PHY and CA and their interaction on $\mathrm{ADC} \%$ of minerals in L. rohita fingerlings fed on canola meal based diet are summarized in Table III. The supplementation of PHY and CA showed positive effects on the growth performance of fish (data not shown). Main effect data indicate that dietary addition of PHY enhanced the minerals digestibility significantly $(p<0.05)$ as compare to control group (D1). Highest $(p<0.05)$ digestibility of $\mathrm{Ca}, \mathrm{P}$ and $\mathrm{Na}$ was observed at $1000 \mathrm{FTU} /$ $\mathrm{kg}$ PHY level while other minerals $(\mathrm{K}, \mathrm{Mg}, \mathrm{Fe}, \mathrm{Cu}, \mathrm{Mn}$ and $\mathrm{Zn}$ ) showed non-significant difference among $1000 \mathrm{FTU} /$ $\mathrm{kg}$ and $2000 \mathrm{FTU} / \mathrm{kg}$ PHY levels.

The main effect data of CA supplementation also showed improved $\mathrm{ADC} \%$ of all the observed minerals compared to fish fed on diet without $\mathrm{CA}$ addition. $\mathrm{Ca}$, $\mathrm{P}, \mathrm{Na}, \mathrm{K}, \mathrm{Mg}, \mathrm{Fe}$ and $\mathrm{Cu}$ showed significantly $(p<0.05)$ enhanced $\mathrm{ADC} \%$ while non-significant $(p<0.05)$ increase was observed for $\mathrm{Mn}$ and $\mathrm{Zn}$. Highest ADC $\%$ of $\mathrm{Ca}, \mathrm{P}, \mathrm{Na}$, $\mathrm{K}, \mathrm{Mg}, \mathrm{Fe}, \mathrm{Cu}, \mathrm{Mn}$ and $\mathrm{Zn}$ were $46.77 \%, 54.27 \%, 53.53 \%$, $45.55 \%, 36.74 \%, 35.32 \%, 48.33 \%, 48.57 \%$ and $47.25 \%$, respectively in diet supplemented with $3 \% \mathrm{CA}$.

Acidification of PHY treated diet with CA significantly $(p<0.05)$ improved the mineral digestibility performance. $\mathrm{Ca}, \mathrm{P}, \mathrm{Na}, \mathrm{K}$ and $\mathrm{Mg}$ showed higher $\mathrm{ADC} \%$ at the level of $3 \% \mathrm{CA}$ and $1000 \mathrm{FTU} / \mathrm{kg}$ PHY. ADC $\%$ of $\mathrm{Mn}$ and $\mathrm{Zn}$ was higher at $1.5 \%$ and $1000 \mathrm{FTU} / \mathrm{kg}$ levels of CA and $\mathrm{PHY}$, respectively. Digestibility of $\mathrm{Fe}$ and $\mathrm{Cu}$ was higher at $2000 \mathrm{FTU} / \mathrm{kg}$ PHY level with $1.5 \%$ and $3 \%$ CA levels, respectively.

\section{DISCUSSION}

In the current study, PHY supplementation increased $(p<0.05)$ the minerals digestibility compared to the fish fed on control diet. This may attribute to phytate hydrolyzing tendency of PHY. Phytate, which is an anti-nutritional factor and interacts with various minerals directly or indirectly and reduces their availability to the fish (Sandberg et al., 1993). Thus, addition of PHY in plant ingredients based feed hydrolyzed the phytate and released bound minerals (Debnath et al., 2005; Baruah et al., 2007).

Results of present study showed clearly that CA acidification of diet also enhanced the absorption of minerals in the body of fingerlings. Citric acid enhances the absorption of minerals by solubilizing the bones present in fish meal (Sarker et al., 2005) and by chelating the $\mathrm{Ca}$ and $\mathrm{P}$ from phytate, which make the phytate more susceptible for hydrolysis (Khajepour and Hosseini, 2010). It also compete with various dietary inhibitors of minerals and increases their bioavailability to fish (Ashmead, 1993). 
Similar increase in $\mathrm{P}$ absorption by supplementing 3\% CA was also observed by Baruah et al. (2007) in rohu, L. rohita and by Khajepour and Hosseini (2012) in Beluga, Huso huso. However, Sarker et al. (2007) observed increased P absorption at 1\% CA level in Red Sea bream, Pagrus major. Baruah et al. (2007) also observed improved digestibility of $\mathrm{Na}, \mathrm{P}, \mathrm{K}, \mathrm{Mn}, \mathrm{Mg}, \mathrm{Fe}, \mathrm{N}, \mathrm{Ca}$ and $\mathrm{Cu}$ by supplementing $3 \% \mathrm{CA}$ in plant based diet.

In the present study, interaction data revealed a positive effect of acidification of diet with CA on PHY effectiveness for mineral absorption. Citric acid along with phytate hydrolysis also provided favorable conditions to PHY action by lowering the gut PH of fish (Baruah et al., 2005). Similar synergistic effect was also shown by common carp, Cyprinus carpio (Phromkunthong et al., 2010) and rohu, L. rohita (Baruah et al., 2005) for $\mathrm{P}$ digestibility. Improved $\mathrm{Zn}$ absorption by PHY and CA supplementation was observed by Brenes et al. (2003) in chick. Baruah et al. (2007) also observed a positive interaction of both additives for $\mathrm{Na}, \mathrm{K}, \mathrm{Zn}, \mathrm{Mn}, \mathrm{Mg}, \mathrm{Cu}$, $\mathrm{Fe}, \mathrm{Ca}$ and $\mathrm{N}$ in rohu, L. rohita fingerlings.

\section{CONCLUSION}

CA and PHY supplementation to plant protein based diet efficiently improved the mineral digestibility performance of $L$. rohita fingerlings by acting individually and further improved by acting synergistically. The supplements showed the potential to prepare cost effective and environment friendly feed by minimizing the mineral supplementation and their discharge into natural water bodies.

\section{Statement of conflict of interest}

Authors have declared no conflict of interest.

\section{REFERENCES}

Allan, G.L. and Rowland, S.J., 1992. Development of an experimental diet for silver perch (Bidyanus bidyanus). Austasia. Aquacult., 6: 39-40.

AOAC, 1995. Official methods of analysis, $15^{\text {th }} \mathrm{Ed}$. Association of Official Analytical Chemists, Washington, D.C. USA., pp. 1094.

Ashmead, H. 1993. The roles of amino acid chelates in animal nutrition. Noyes Publications, Park Ridge, NJ. pp. 479.

Baruah, K., Pal, A.K., Sahu, N.P. and Debnath, D., 2007. Interactions of dietary microbial phytase, citric acid and crude protein level on mineral utilization by rohu (Labeo rohita) juveniles. J. World Aquacult. Soc., 38: 129-137. https://doi.org/10.1111/j.1749- 7345.2007.00092.x

Baruah, K., Pal, A.K., Sahu, N.P., Jain, K.K., Mukherjee, S.C. and Debnath, D., 2005. Dietary protein level, microbial phytase, citric acid and their interactions on digestibility of Labeo rohita juveniles. Aquacult. Res., 36: 803-812. https://doi.org/10.1111/j.13652109.2005.01290.x

Bell, J.M., 1993. Factors affecting the nutritional value of canola meal: A review. Can. J. Anim. Sci., 73: 679-697. https://doi.org/10.4141/cjas93-075

Brenes, A., Viveros, A., Arija, I., Centeno, C., Pizzaro, M. and Bravo, C., 2003. The effect of citric acid and microbial phytase on mineral utilization in broiler chicks. Anim. Feed Sci. Technol., 110: 201-219. https://doi.org/10.1016/S0377-8401(03)00207-4

Debnath, D., Pal, A.K., Narottam, P.S., Jain, K.K., Yengkokpam, S. and Mukherjee, S.C., 2005. Effect of dietary microbial phytase supplementation on growth and nutrient digestibility of Pangasius pangasius (Hamilton) fingerlings. Aquacult. Res., 36: 180-187. https://doi.org/10.1111/j.13652109.2004.01203.x

Divakaran, S., Leonard, G.O. and Ian, P.F., 2002. Note on the methods for determination of chromic oxide in shrimp feeds. J. Agric. Fd. Chem., 50: 464-467. https://doi.org/10.1021/jf011112s

Engelen, A.J., Vander-Heeft, F.C., Randsdrop, P.H.G. and Smith, E.L.C., 1994. Simple and rapid determination of phytase activity. J. AOAC Int., 77: 760-764.

Khajepour, F. and Hosseini, S.A., 2010. Mineral status of juvenile beluga (Huso huso) fed citric acid supplemented diets. World appl. Sci. J., 11: 682686.

Khajepour, F. and Hosseini, S.A., 2012. Calcium and phosphorus status in juvenile Beluga (Huso huso) fed citric acid-supplemented diets. Aquacult. Res., 43: 407-411. https://doi.org/10.1111/j.13652109.2011.02843.x

Khajepour, F. and Hosseini, S.A., 2011. Effect of dietary citric acid supplementation and partial replacement of dietary fish meal with soybean meal on calcium and phosphorus of muscle, scute and serum of Beluga, Huso huso. Afr. J. Biotechnol., 10: 1465214655. https://doi.org/10.5897/AJB11.1312

Kumar, V., Sinha, A.K., Makkar, H.P. and Becker, K., 2010. Dietary roles of phytate and phytase in human nutrition: A review. Fd. Chem., 120: 945-959. https://doi.org/10.1016/j.foodchem.2009.11.052

Laining, A., Ishikwa, M., Kyaw, K., Gao, J., Binh, N.T., Koshio, S., Yamaguchi, S., Yokoyama, S. and Koyama, J., 2010. Dietary calcium/phosphorous 
ratio influences the efficacy of microbial phytase on growth, minerals digestibility and vertebral mineralization in juvenile tiger puffer, Takifugu rubripes. Aquacult. Nutr., 17: 267-277. https://doi. org/10.1111/j.1365-2095.2009.00749.x

NRC, 1993. Nutrient requirements of fish. Nat. Acad. Press, National Research Council, Washington, DC, pp. 114.

Nwanna, L.C., 2005. Effect of toasting and incubation of soybean meal supplemented with phytase in practical diets on the growth and mineral deposition in Nile tilapia. J. Anim. Vet. Adv., 4: 234-239.

Ogino, C., Takeuchi, L., Takeda, H. and Watanabe T., 1979. Availability of dietary phosphorus in carp and rainbow trout. B. JPN. Soc. Sci. Fish., 45: 1527-1532. https://doi.org/10.2331/suisan.45.1527

Persson, H., Turk, M., Nyman, M. and Sandberg, A.S., 1998. Binding of $\mathrm{Cu}^{2+}, \mathrm{Zn}^{2+}$, and $\mathrm{Cd}^{2+}$ to inositol tri-, tetra-, penta-, and hexa-phosphates. J. Agric. Fd. Chem., 46: 3194-3200. https://doi.org/10.1021/ jf9810362

Phromkunthong, W., Nuntapong, N. and Gabaudan, J., 2010. Interaction of phytase RONOZYME and citric acid on the utilization of phosphorus by common carp (Cyprinus carpio). Songklanakarin J. Sci. Technol., 32: 124-132.

Robinson, E.H., Li, M.H. and Manning, B.B., 2002. Comparison of microbial phytase and dicalcium phosphate for growth and bone mineralization of pond-raised channel catfish (Ictalurus punctatus). J. appl. Aquacult., 12: 81-88. https://doi.org/10.1300/ J028v12n03_08

Rowland, S.J. and Ingram, B.A., 1991. Diseases of Australian native fishes. In: Fisheries bulletin 4 NSW Fisheries, Sydney, NSW, Australia.

Sandberg, A.S., Larsen, T. and Sabdstrom, B., 1993. Phytase of the yeast (Arxula adeninivorans).
Biotechnol. Lett., 21: 33-38.

Sarker, S.A., Satoh, S. and Kiron, V., 2007. Inclusion of citric acid and amino acid chelated trace elements in alternate plant protein source diets affects growth and excretion of nitrogen and phosphorus in red sea bream (Pagrus major). Aquaculture, 262: 436-443. https://doi.org/10.1016/j.aquaculture.2006.10.007

Sarker, S.A., Satoh, S. and Kiron, V., 2005. Supplementation of citric acid and amino acid chelated trace element to develop environmentfriendly feed for red sea bream, Pagrus major. Aquaculture, 248: 3-11. https://doi.org/10.1016/j. aquaculture.2005.04.012

Snedecor, G.W. and Cochran, W.G., 1991. Statistical methods, $8^{\text {th }} E d$. Iowa State Univ. Press, Ames. USA, pp. 503.

Steel, R.G.D., Torrie, J.H. and Dickey, D.A., 1996. Principles and procedures of statistics, $3^{\text {rd }} \mathrm{Ed}$. McGraw Hill International Book Co. Inc., New York, USA, pp. 336-352.

Sugiura, S.H., Gabaudan J., Dong, F.M. and Hardy, R.W., 2001. Dietary microbial phytase supplementation and the utilization of phosphorus, trace minerals and protein by rainbow trout Oncorhynchus mykiss (W) fed soybean meal-based diets. Aquacult. Res., 32: 583-592. https://doi.org/10.1046/j.13652109.2001.00581.x

Usmani, N. and Jafri, A.K., 2002. Influence of dietary phytic acid on the growth, conversion efficiency and carcass composition of Cirrhinus mrigala $(\mathrm{H})$ fry. J. World. Aquacult. Soc., 33: 199-204. https:// doi.org/10.1111/j.1749-7345.2002.tb00495.x

Zyla, K., Ledoux, D.R., Garcia, A. and Veum, T.L., 1995. An in vitro procedure for studying enzymatic phosphorylation of phytate in maize-soybean feeds for turkey poults. Braz. J. Nutr., 74: 3-17. https:// doi.org/10.1079/BJN19950102 